\title{
Association of kidney disease measures with risk of renal function worsening in patients with type 1 diabetes
}

\author{
Antonio Mirijello ${ }^{1 *}$ DD, Francesca Viazzi ${ }^{2}$, Paola Fioretto ${ }^{3}$, Carlo Giorda ${ }^{4}$, Antonio Ceriello ${ }^{5,6}$, Giuspina T. Russo ${ }^{7}$, \\ Pietro Guida ${ }^{8}$, Roberto Pontremoli ${ }^{9}$, Salvatore De Cosmo ${ }^{1 *}$ and on behalf of the AMD ANNALS Study Group
}

\begin{abstract}
Background: Albuminuria has been classically considered a marker of kidney damage progression in diabetic patients and it is routinely assessed to monitor kidney function. However, the role of a mild GFR reduction on the development of stage $\geq 3$ CKD has been less explored in type 1 diabetes mellitus (T1DM) patients. Aim of the present study was to evaluate the prognostic role of kidney disease measures, namely albuminuria and reduced GFR, on the development of stage $\geq 3$ CKD in a large cohort of patients affected by T1DM.

Methods: A total of 4284 patients affected by T1DM followed-up at 76 diabetes centers participating to the Italian Association of Clinical Diabetologists (Associazione Medici Diabetologi, AMD) initiative constitutes the study population. Urinary albumin excretion (ACR) and estimated GFR (eGFR) were retrieved and analyzed. The incidence of stage $\geq 3$ CKD (eGFR $<60 \mathrm{~mL} / \mathrm{min} / 1.73 \mathrm{~m} 2$ ) or eGFR reduction $>30 \%$ from baseline was evaluated.

Results: The mean estimated GFR was $98 \pm 17 \mathrm{~mL} / \mathrm{min} / 1.73 \mathrm{~m}^{2}$ and the proportion of patients with albuminuria was $15.3 \%(n=654)$ at baseline. About $8 \%(n=337)$ of patients developed one of the two renal endpoints during the 4-year follow-up period. Age, albuminuria (micro or macro) and baseline eGFR $<90 \mathrm{ml} / \mathrm{min} / \mathrm{m}^{2}$ were independent risk factors for stage $\geq 3$ CKD and renal function worsening. When compared to patients with eGFR $>90 \mathrm{ml} / \mathrm{min} / 1.73 \mathrm{~m}^{2}$ and normoalbuminuria, those with albuminuria at baseline had a 1.69 greater risk of reaching stage 3 CKD, while patients with mild eGFR reduction (i.e. eGFR between 90 and $60 \mathrm{~mL} / \mathrm{min} / 1.73 \mathrm{~m} 2$ ) show a 3.81 greater risk that rose to 8.24 for those patients with albuminuria and mild eGFR reduction at baseline.

Conclusions: Albuminuria and eGFR reduction represent independent risk factors for incident stage $\geq 3$ CKD in T1DM patients. The simultaneous occurrence of reduced eGFR and albuminuria have a synergistic effect on renal function worsening.
\end{abstract}

Keywords: GFR, Albuminuria, Diabetic kidney disease

\section{Background}

Diabetes represents the primary cause of end-stage renal disease (ESRD) in most of industrialized Countries [1]. It plays a synergistic role together with hypertension and ageing in the pathogenesis of renal disease [2]. The prevalence of diabetic nephropathy is constantly increasing $[3$,

\footnotetext{
* Correspondence: antonio.mirijello@gmail.com; a.mirijello@operapadrepio.it; s.decosmo@operapadrepio.it

${ }^{1}$ Department of Medical Sciences, Scientific Institute "Casa Sollievo della Sofferenza", IRCCS Casa Sollievo della Sofferenza, v.le Cappuccini, 71013 San Giovanni Rotondo, FG, Italy

Full list of author information is available at the end of the article
}

4] accounting for a significant morbidity, mortality and reduction of Quality of Life (QoL) [5].

Diabetic kidney disease (DKD) is a serious complication of both forms of diabetes [4], involving about 25$75 \%$ of patients with type 1 diabetes (T1DM) [4, 6] and about $30-40 \%$ of those with type 2 diabetes (T2DM) [4]. Historically DKD has been defined as an increased urinary albumin excretion (i.e. microalbuminuria) that appears about 5 to 10 years after the onset of diabetes and, if untreated, progresses, in a period of $10-15$ years, to macroalbuminuria (i.e. proteinuria) and to reduced

(c) The Author(s). 2018 Open Access This article is distributed under the terms of the Creative Commons Attribution 4.0 International License (http://creativecommons.org/licenses/by/4.0/), which permits unrestricted use, distribution, and 
glomerular filtration rate (GFR), and further on to ESRD [4]. Thus, the search and periodic evaluation of microalbuminuria for the diagnosis and follow-up of diabetic nephropathy has become part of routine clinical practice [7].

However, recent evidence suggests the increasing prevalence of a different pathway of DKD characterized by a decline of GFR (even) in the absence of micro and/ or macroalbuminuria [6, 8-10].

Over the last decades, besides the identification of genetic predisposing factors [3, 11, 12], several environmental determinants [7] for the development and progression of kidney dysfunction in patients with T1DM have been described. Among these, hyperglycemia, dyslipidemia, increased blood pressure (BP) and smoking have been emphasized to bear a relevant unfavorable effect on renal function $[6,9,13,14]$.

In patients with T1DM, increased levels of albuminuria are not only a well-known manifestation of diabetic renal involvement, but also an established marker of renal damage progression. Longitudinal studies have demonstrated that GFR declines in parallel with the increase in urinary albumin excretion and Perkins and co-workers have shown a significant correlation between the rate of GFR decline with progressive stages of albuminuria [15]. In this context, the role of a mild, isolated GFR reduction on the development of stage $\geq 3$ CKD has been less explored in T1DM patients.

Aim of the present study was to evaluate the independent prognostic role of kidney disease measures, namely albuminuria and reduced GFR, on the development of stage $\geq 3$ CKD in a large cohort of patients affected by T1DM.

\section{Methods}

\section{Study setting, patients and data sources}

The study population is represented by patients affected by T1D followed-up at 155 Italian diabetes centers participating to the Italian Association of Clinical Diabetologists initiative (Associazione Medici Diabetologi, AMD). Electronic medical records collected between January 2004 and June 2008 were analyzed. Data set of patients $\geq 18$ years old, with a follow-up within $48 \pm 6$ months, and no missing data concerning BP values, estimated GFR (eGFR), baseline evaluation of HbA1c, albuminuria classification, triglycerides, HDL and LDL were evaluated.

Of 6298 patients identified, 2014 have been excluded for the reasons showed in Fig. 1.

The final study population is represented by 4284 patients affected by T1DM from 76 clinics homogeneously distributed throughout the Country.

\section{Methods and data collection}

As previously reported [6, 9, 16-19], the Italian Association of Clinical Diabetologists (Associazione Medici Diabetologi,
AMD) initiative and its clinical database were set up to recognize a set of indicators to be used for continuous quality improvement. The software for medical management of outpatients is the same among all centers. Patients' data recorded are anonymized under a unique identification ID, encrypted to protect patients' privacy. Clinical information collected from all centers can be anonymously extracted and centrally analyzed (AMD Data File) [16-19]. The automated system prevents the identification of individual patients. Thus, according to Italian law ethical committee approval and informed consent were not required. Results were internally revised and approved by AMD Annals Scientific Committee.

This initiative includes the measurement and monitoring of HbA1c, BP, low-density lipoprotein (LDL-c), total and high density lipoprotein cholesterol (HDL-c) and triglycerides, together with the evaluation of the use of specific classes of drugs (insulin, statins and two or more anti-hypertensive agents). Given the variability of normal ranges among centers, in order to allow comparisons, the estimated percentage change (measured value/upper normal limit) was multiplied by 6.0 . The measurement of TG, performed by enzymaticcolorimetric or by ORTHO instrumentation had the same normal range. Even for HDL-C, normal range and decisional levels were the same.

Serum creatinine and urinary albumin excretion were used to assess kidney function. GFR was estimated by using a standardized serum creatinine assay and the Chronic Kidney Disease Epidemiology Collaboration formula [20]. Increased urinary albumin excretion was diagnosed as: i. microalbuminuria if urinary albumin concentration was $>30$ and $\leq 300 \mathrm{mg} / \mathrm{L}$, or if urinary albumin excretion rate was $>20$ and $\leq 200 \mu \mathrm{g} / \mathrm{min}$, or if urinary albumin-to-creatinine ratio (ACR) was $>2.5 \mathrm{mg} /$ $\mathrm{mmol}$ in men and $>3.5 \mathrm{mg} / \mathrm{mmol}$ in women and $\leq 30$ $\mathrm{mg} / \mathrm{mmol}$ in both gender; ii. macroalbuminuria if urinary albumin concentration was $>300 \mathrm{mg} / \mathrm{L}$, or if urinary albumin excretion rate was $>200 \mu \mathrm{g} / \mathrm{min}$, or if ACR was $>30 \mathrm{mg} / \mathrm{mmol}$ in both gender. Albuminuria indicates patients with either micro or macroalbuminuria. In the present study, albuminuria determination was based on a single issue [21].

Physical examination and BP measurement were performed by a standardized protocol [6, 9, 16-19].

DKD was defined as diabetes with albuminuria or low eGFR (i.e. $<60 \mathrm{~mL} / \mathrm{min} / 1.73 \mathrm{~m} 2$ ) or both.

\section{Renal outcomes}

The outcomes were: i. stage $\geq 3$ CKD, i.e. an eGFR $<60$ $\mathrm{mL} / \mathrm{min} / 1.73 \mathrm{~m}^{2}$; ii. eGFR reduction $>30 \%$ as compared to baseline; iii. The combination of either one of the two previous endpoints. 


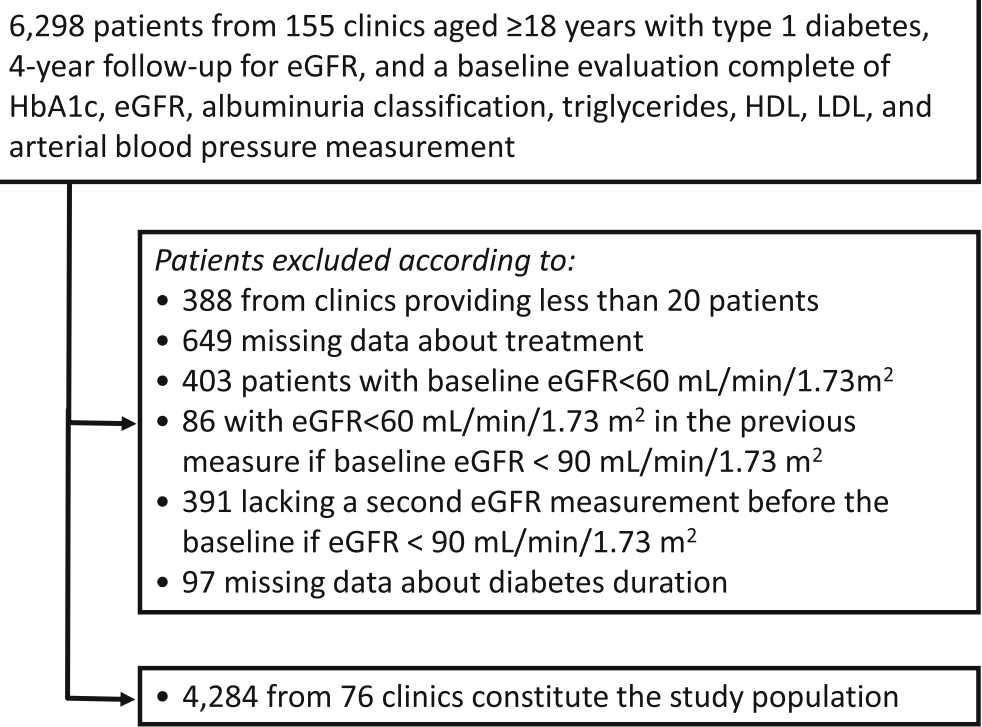

Fig. 1 Study population: inclusion and exclusion criteria

\section{Statistical analysis}

Data are given as mean values \pm standard deviation (SD); categorical variables are described as frequencies and percentages. Linear and logistic regression models were used to evaluate variables associated to, respectively, continuous and categorical data. To consider possible differences in data across diabetes clinics, mixed models were fitted with the enrolling centers as random effect. For each renal outcome were reported odds ratios (ORs) with their 95\% confidence intervals (95\% CIs). Multivariate models were fitted including a missing indicator variable (for BMI) and a complete-case analysis was also performed including only patients with all data available (models including serum uric acid and smoke status). The analyses were made using STATA software, version 14 (StataCorp, College Station, Texas). $P$ values of $<0.05$ were considered statistically significant.

\section{Results}

Table 1 summarizes the main clinical features of the study population at baseline, overall and on the basis of the presence/absence of albuminuria. Table 2 summarizes the number and percentage of patients who reached one of the renal outcome at 4 year follow-up (Table 2).

The mean age was $45 \pm 14$ years ( $56.8 \%$ male). Mean diabetes duration was $18 \pm 12$ years. The glyco-metabolic status of participants was rather unfair, being the mean values of HbA1c and LDL-c of $7.8 \pm 1.4 \%$ and $110 \pm 31$ $\mathrm{mg} / \mathrm{dL}$, respectively. The average BP was $126 \pm 17 / 76 \pm$ $9 \mathrm{mmHg}$; about $30.6 \%$ of patients had BP >140/85 $\mathrm{mmHg}$ at baseline. More than a quarter of patients were receiving antihypertensive treatment and $23.4 \%$ were taking an ACE-I or an ARB. The mean eGFR was $98 \pm$ $17 \mathrm{~mL} / \mathrm{min} / 1.73 \mathrm{~m} 2$ and the proportion of patients with albuminuria was $15.3 \%(n=654)$. Patients showing baseline albuminuria had a worse risk profile, such as longer duration of disease, higher BMI, serum uric acid, HbA1c, a more atherogenic lipid profile (i.e. higher triglycerides and LDL values). Moreover, they showed higher BP despite more antihypertensive and lipid lowering treatments.

Additional file 1: Table S1 reports the baseline clinical features of patients grouped on the basis of the achieved renal outcome within the study period. On average, patients who went on to develop low eGFR (i.e. $<60 / \mathrm{ml} / \mathrm{min} / 1.73 \mathrm{~m}^{2}$ or eGFR reduction $>30 \%$ ) showed a worse clinical profile. Older age, longer duration of diabetes and worse glycemic control were associated with the achievement of both renal outcomes while baseline eGFR was lower only among patients who developed stage $\geq 3$ CKD. Patients who developed stage $\geq 3$ CKD showed also significantly higher BP values at baseline, despite a higher prevalence of antihypertensive treatment, even with ACE-I or ARB.

The cumulative number of patients with a first occurrence of any of the two renal endpoints steadily increased during the study period (Fig. 2 a-c), with an incidence of $2.12 \%$ per year. Of the 4284 evaluated patients, 238 patients (5.6\%) developed stage $\geq 3$ CKD within the 4-year follow-up period (Table 2 and Fig. 2a), while 215 patients (5\%) showed a $>30 \%$ decrease in eGFR as compared to baseline (Table 2 and Fig. 2b) and 337 patients $(7.9 \%)$ shower the combination of these two endpoints (Table 2 and Fig. 2c). 
Table 1 Baseline clinical characteristics of patients grouped by the presence of albuminuria

\begin{tabular}{|c|c|c|c|c|c|}
\hline & $\begin{array}{l}\text { All } \\
n=4284\end{array}$ & $\begin{array}{l}\text { Normoalbuminuria } \\
n=3630\end{array}$ & $\begin{array}{l}\text { Microalbuminuria } \\
n=557\end{array}$ & $\begin{array}{l}\text { Macroalbuminuria } \\
n=97\end{array}$ & $p$ \\
\hline Male sex & $2432(56.8 \%)$ & $2009(55.3 \%)$ & $363(65.2 \%)$ & $60(61.9 \%)$ & $<0.001$ \\
\hline Age (years) & $45 \pm 14$ & $44 \pm 14$ & $47 \pm 14$ & $48 \pm 12$ & 0.006 \\
\hline Known duration of diabetes (years) & $18 \pm 12$ & $17 \pm 12$ & $20 \pm 12$ & $25 \pm 11$ & $<0.001$ \\
\hline $\mathrm{BMI}\left(\mathrm{Kg} / \mathrm{m}^{2}\right)$ & $24.5 \pm 3.6$ & $24.4 \pm 3.5$ & $25.0 \pm 3.7$ & $25.4 \pm 3.8$ & 0.003 \\
\hline Serum creatinine $(\mathrm{mg} / \mathrm{dL})$ & $0.84 \pm 0.17$ & $0.84 \pm 0.16$ & $0.86 \pm 0.17$ & $0.91 \pm 0.21$ & $<0.001$ \\
\hline eGFR $\left(\mathrm{mL} / \mathrm{min} / 1.73 \mathrm{~m}^{2}\right)$ & $98 \pm 17$ & $99 \pm 17$ & $96 \pm 16$ & $91 \pm 18$ & $<0.001$ \\
\hline Serum uric acid (mg/dL) & $3.9 \pm 1.4$ & $3.8 \pm 1.4$ & $4.2 \pm 1.2$ & $4.6 \pm 1.2$ & $<0.001$ \\
\hline Serum uric acid in the top quintile & 447 (18.3\%) & $361(17.0 \%)$ & $65(24.5 \%)$ & $21(40.4 \%)$ & $<0.001$ \\
\hline $\mathrm{HbA} 1 \mathrm{c}(\%)$ & $7.8 \pm 1.4$ & $7.7 \pm 1.4$ & $8.0 \pm 1.4$ & $8.3 \pm 1.4$ & $<0.001$ \\
\hline $\mathrm{HbA1c} \geq 7 \%$ & $3071(71.7 \%)$ & $2555(70.4 \%)$ & $435(78.1 \%)$ & $81(83.5 \%)$ & 0.001 \\
\hline Total cholesterol (mg/dL) & $190 \pm 36$ & $189 \pm 35$ & $188 \pm 38$ & $205 \pm 42$ & $<0.001$ \\
\hline Triglycerides (mg/dL) & $87 \pm 79$ & $85 \pm 81$ & $97 \pm 64$ & $117 \pm 70$ & $<0.001$ \\
\hline Triglycerides $\geq 150 \mathrm{mg} / \mathrm{dl}$ & $360(8.4 \%)$ & $275(7.6 \%)$ & $65(11.7 \%)$ & $20(20.6 \%)$ & $<0.001$ \\
\hline $\mathrm{HDL}(\mathrm{mg} / \mathrm{dL})$ & $62 \pm 18$ & $62 \pm 18$ & $60 \pm 19$ & $61 \pm 17$ & 0.089 \\
\hline $\mathrm{HDL}<40 \mathrm{M}<50 \mathrm{~F} \mathrm{mg} / \mathrm{dL}$ & $501(11.7 \%)$ & $408(11.2 \%)$ & $80(14.4 \%)$ & $13(13.4 \%)$ & 0.208 \\
\hline $\mathrm{LDL}(\mathrm{mg} / \mathrm{dL})$ & $110 \pm 31$ & $110 \pm 31$ & $109 \pm 32$ & $121 \pm 35$ & 0.001 \\
\hline $\mathrm{LDL} \geq 100 \mathrm{mg} / \mathrm{dL}$ & $2638(61.6 \%)$ & $2244(61.8 \%)$ & $324(58.2 \%)$ & $70(72.2 \%)$ & 0.012 \\
\hline Systolic BP (mmHg) & $126 \pm 17$ & $125 \pm 17$ & $130 \pm 19$ & $137 \pm 22$ & $<0.001$ \\
\hline Diastolic BP (mmHg) & $76 \pm 9$ & $75 \pm 9$ & $77 \pm 9$ & $80 \pm 11$ & $<0.001$ \\
\hline $\mathrm{BP} \geq 140 / 85 \mathrm{mmHg}$ & $1310(30.6 \%)$ & $1039(28.6 \%)$ & $218(39.1 \%)$ & $53(54.6 \%)$ & $<0.001$ \\
\hline Non-proliferative retinopathy & $925(21.6 \%)$ & $744(20.5 \%)$ & $149(26.8 \%)$ & $32(33.0 \%)$ & 0.018 \\
\hline Proliferative retinopathy & $321(7.5 \%)$ & $232(6.4 \%)$ & $72(12.9 \%)$ & $17(17.5 \%)$ & $<0.001$ \\
\hline Smokers & $602(27.9 \%)$ & $515(27.3 \%)$ & $72(31.6 \%)$ & $15(38.5 \%)$ & 0.119 \\
\hline Lipid-lowering treatment & $861(20.1 \%)$ & $664(18.3 \%)$ & $162(29.1 \%)$ & $35(36.1 \%)$ & $<0.001$ \\
\hline Treatment with statins & $822(19.2 \%)$ & $638(17.6 \%)$ & $153(27.5 \%)$ & $31(32.0 \%)$ & $<0.001$ \\
\hline Treatment with fibrates & $19(0.4 \%)$ & $13(0.4 \%)$ & $4(0.7 \%)$ & $2(2.1 \%)$ & 0.045 \\
\hline Antihypertensive treatment & $1102(25.7 \%)$ & $779(21.5 \%)$ & $249(44.7 \%)$ & $74(76.3 \%)$ & $<0.001$ \\
\hline Treatment with ACE-Is/ARBs & $1001(23.4 \%)$ & 699 (19.3\%) & $231(41.5 \%)$ & $71(73.2 \%)$ & $<0.001$ \\
\hline Aspirin & $425(9.9 \%)$ & $310(8.5 \%)$ & $93(16.7 \%)$ & $22(22.7 \%)$ & $<0.001$ \\
\hline Insulin pump & $304(7.1 \%)$ & $269(7.4 \%)$ & $29(5.2 \%)$ & $6(6.2 \%)$ & 0.563 \\
\hline
\end{tabular}

Mean \pm SD or absolute frequency (percentage). $B M I$ body mass index, $B P$ blood pressure, $H b A 1 c$ glycated haemoglobin, $H D L$ high-density lipoprotein cholesterol, $L D L$ low-density lipoprotein cholesterol, eGFR estimated glomerular filtration rate, SBP systolic blood pressure, DBP diastolic blood pressure, $A C E-I s$ angiotensin converting enzyme-inhibitors, ARBs angiotensin II receptor antagonists. Patients' baseline missing data: BMI in 176 (4.1\%), serum uric acid in 1847 (43.1\%), total cholesterol in $58(1.4 \%)$, and smoking status in 2128 (49.7\%). Serum uric acid the top gender-specific quintile: $\geq 4.0 \mathrm{mg} / \mathrm{dL}$ for females and $\geq 5.1 \mathrm{mg} / \mathrm{dL}$ for males. The $p$ value refers to overall statistical significance of a mixed logistic regression model for categorical variables or mixed linear regression model for continuous variables with microalbuminuria and macroalbuminuria as covariate

Table 2 Four-year renal outcome of patients grouped by the presence of albuminuria

\begin{tabular}{llllll}
\hline & All & Normoalbuminuria & Microalbuminuria & Macroalbuminuria & $p$ \\
& $n=4284$ & $n=3630$ & $n=557$ & $43(7.7 \%)$ & $20(20.6 \%)$ \\
\hline GFR $<60 \mathrm{~mL} / \mathrm{min} / 1.73 \mathrm{~m}^{2}$ & $238(5.6 \%)$ & $175(4.8 \%)$ & $42(7.5 \%)$ & $19(19.6 \%)$ & $<0.001$ \\
GFR reduction $>30 \%$ than baseline & $215(5.0 \%)$ & $154(4.2 \%)$ & $56(10.1 \%)$ & $26(26.8 \%)$ & $<0.001$ \\
GFR $<60$ or reduction $>30 \%$ & $337(7.9 \%)$ & $255(7.0 \%)$ & 0.001 \\
\hline
\end{tabular}



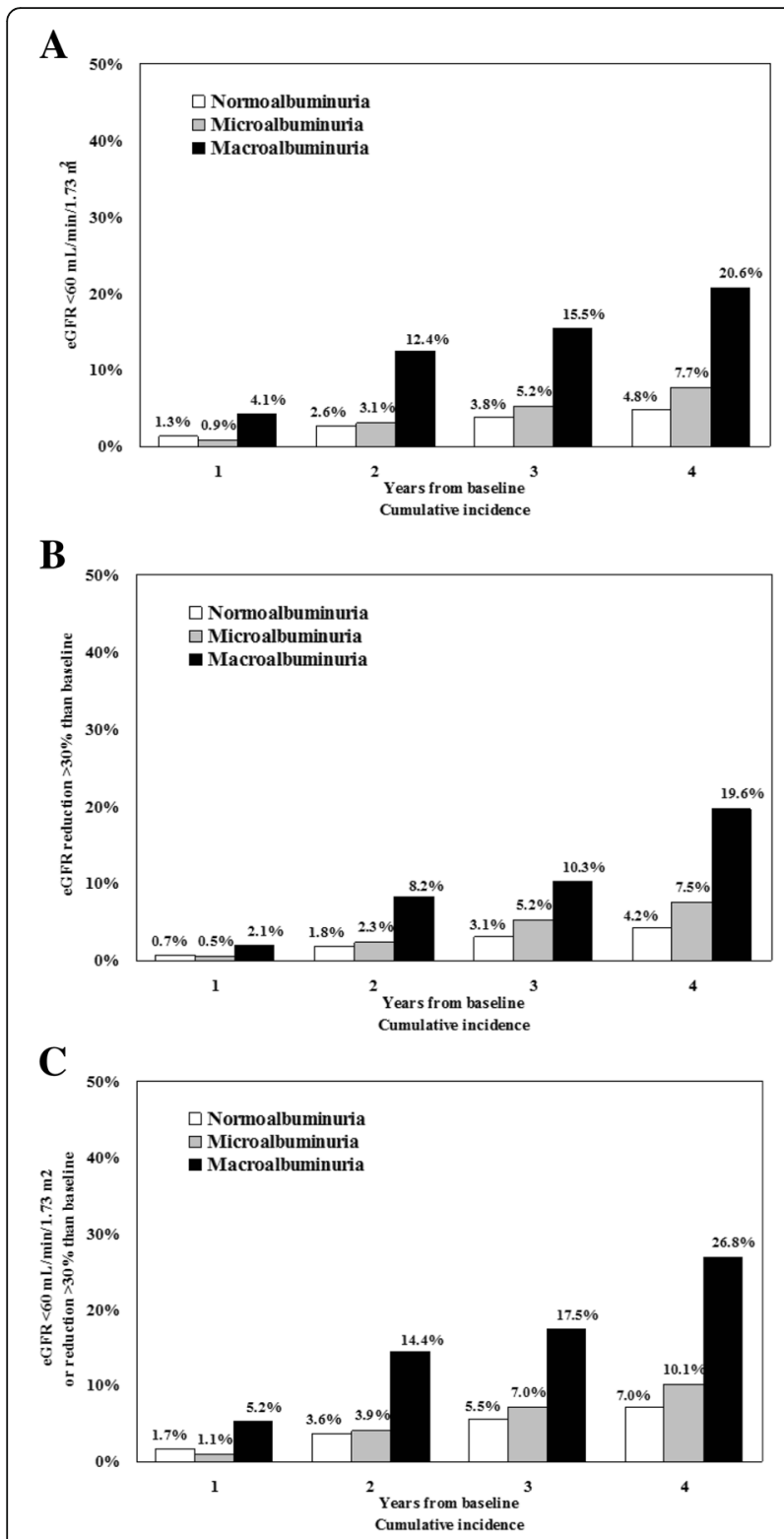

Fig. 2 Year cumulative incidence of anyone of the two renal endpoints ((a) eGFR< $60 \mathrm{~mL} / \mathrm{min} / 1.73 \mathrm{~m}^{2}$; (b) eGFR reduction > 30\% from baseline; (c) both endpoints) during 4-year follow-up

At multivariate analysis, age, albuminuria (micro and macro) and baseline eGFR $<90 \mathrm{ml} / \mathrm{min} / \mathrm{m} 2$ remained independently and significantly associated to a higher risk of incident stage $\geq 3 \mathrm{CKD}$ and renal function worsening (Table 3). The duration of diabetes, BMI, baseline HbA1c and $\mathrm{BP}$ values did not significantly influence the outcome (Table 3). As for lipid profile, neither HDL nor LDL cholesterol levels significantly influence the outcome. On the contrary, a significant association with higher TG levels and eGFR reduction $>30 \%$ at 4-years was found (Table 3 ).

To better investigate the role of albuminuria and eGFR values on renal outcomes, patients were stratified based on the baseline eGFR ( $>90 / 60-90)$ and albuminuria (Alb+/Alb-) (Fig. 3a, Additional file 2: Table S2). Among patients with eGFR values above or below $90 \mathrm{ml} / \mathrm{min} /$ $1.73 \mathrm{~m} 2$ albuminuria was present in 15.9 and $23.2 \%$, respectively (Additional file 2: Table S2). With respect to patients with eGFR $>90 \mathrm{ml} / \mathrm{min} / 1.73 \mathrm{~m}^{2}$ and normoalbuminuria (reference), the OR of developing the composite renal endpoint over 4-year study period was 1.69 (95\%CI $1.08-2.64 ; p=0.021$ ) for patients with albuminuria and baseline eGFR values above $90 \mathrm{~mL} / \mathrm{min}$ and rose progressively to $3.81(95 \% \mathrm{CI} 2.91-4.99 ; p<0.001)$ in patients with normal albumin and eGFR values between 90 and $60 \mathrm{~mL} / \mathrm{min}$ and then further up to 8.24 (95\%CI 5.57-12.17; $p<0.001)$ when albuminuria was concomitant to mild GFR reduction (i.e. GFR between 90 and 60 $\mathrm{mL} / \mathrm{min}$ ) (Fig. 3b).

Figure 4 shows the estimated worsening rate of renal function at any given baseline eGFR. Albuminuria appears as an adjunctive risk factor for the progression to stage $>3$ CKD over the entire study period.

Multivariate OR for the incidence of stage $\geq 3 \mathrm{CKD}$ in patients with a given baseline eGFR and without albuminuria are showed in Fig. 5.

\section{Discussion}

The present study shows that the cumulative incidence of stage $\geq 3$ CKD observed over a 4-year follow-up in a large sample of patients affected by T1DM, representative of real-life Italian clinical practice, is $5.6 \%$. In addition, both albuminuria and mild eGFR reduction independently predict a significant decline of renal function.

The observed rate of onset of stage $\geq 3$ DKD is consistent with that previously reported in other cohorts of patients with similar characteristics [22-25].

Overall, patients who went on to develop stage $\geq 3$ CKD were older and had an unfavorable cardiovascular risk profile at baseline as compared to patients who did not develop renal dysfunction. The former, in fact, had a worse glycemic control, a more atherogenic lipid profile (i.e. lower HDL cholesterol and higher triglycerides), and higher levels of systolic and diastolic blood pressure despite the presence of a more aggressive antihypertensive treatment. Finally, micro or macroalbuminuria were more prevalent among patients who developed stage $\geq 3$ CKD, who had also a lower baseline eGFR value.

In the present work, we have focused on the distinct role of albuminuria and mild eGFR reduction in promoting the onset of stage $\geq 3 \mathrm{CKD}$. In our dataset, albuminuria (i.e. micro or macroalbuminuria) appears to be a strong and independent predictor of kidney function loss. These data confirm and expand previous seminal observation by Viberti and co-workers [26] who first described the role of microalbuminuria as marker of early 
Table 3 Multivariate analysis of renal outcome within 4-year

\begin{tabular}{|c|c|c|c|c|c|c|}
\hline & \multicolumn{2}{|c|}{$\mathrm{eGFR}<60 \mathrm{~mL} / \mathrm{min} / 1.73 \mathrm{~m}^{2}$} & \multicolumn{2}{|c|}{$\begin{array}{l}\text { eGFR reduction }>30 \% \text { than } \\
\text { baseline }\end{array}$} & \multicolumn{2}{|c|}{$\begin{array}{l}\mathrm{eGFR}<60 \mathrm{~mL} / \mathrm{min} / 1.73 \mathrm{~m}^{2} \text { or } \\
\text { reduction }>30 \%\end{array}$} \\
\hline & Odds Ratio $(95 \% \mathrm{Cl})$ & $p$ & Odds Ratio (95\%Cl) & $p$ & Odds Ratio $(95 \% \mathrm{Cl})$ & $p$ \\
\hline Male sex & $0.9(0.65-1.24)$ & 0.512 & $0.53(0.39-0.71)$ & $<0.001$ & $0.59(0.46-0.76)$ & $<0.001$ \\
\hline Age (by 10 years) & $1.91(1.65-2.22)$ & $<0.001$ & $1.38(1.21-1.58)$ & $<0.001$ & $1.46(1.30-1.63)$ & $<0.001$ \\
\hline Duration of diabetes (by 5 years) & $0.95(0.89-1.01)$ & 0.107 & $1.01(0.94-1.08)$ & 0.819 & $0.98(0.93-1.04)$ & 0.500 \\
\hline \multicolumn{7}{|l|}{$B M I$} \\
\hline $27-30 \mathrm{Kg} / \mathrm{m}^{2}$ & $0.93(0.61-1.43)$ & 0.754 & $1.02(0.68-1.53)$ & 0.924 & $1.09(0.77-1.53)$ & 0.636 \\
\hline$>30 \mathrm{Kg} / \mathrm{m}^{2}$ & $1.16(0.67-2.02)$ & 0.599 & $0.92(0.52-1.63)$ & 0.770 & $1.15(0.73-1.81)$ & 0.543 \\
\hline \multicolumn{7}{|l|}{ Albuminuria } \\
\hline Microalbuminuria & $1.55(1.00-2.40)$ & 0.048 & $1.87(1.27-2.76)$ & 0.002 & $1.44(1.01-2.06)$ & 0.045 \\
\hline Macroalbuminuria & $4.30(2.19-8.46)$ & $<0.001$ & $5.12(2.81-9.35)$ & $<0.001$ & $4.09(2.33-7.16)$ & $<0.001$ \\
\hline eGFR below $90 \mathrm{~mL} / \mathrm{min} / 1.73 \mathrm{~m}^{2}$ (by 5) & $1.79(1.64-1.96)$ & $<0.001$ & $0.87(0.78-0.97)$ & 0.014 & $1.46(1.36-1.57)$ & $<0.001$ \\
\hline $\mathrm{HbA} 1 \mathrm{c} \geq 7 \%$ & $1.08(0.73-1.60)$ & 0.695 & $1.17(0.82-1.66)$ & 0.386 & $1.13(0.83-1.53)$ & 0.437 \\
\hline Triglycerides $\geq 150 \mathrm{mg} / \mathrm{dl}$ & $1.48(0.88-2.50)$ & 0.139 & $2.00(1.28-3.12)$ & 0.002 & $1.84(1.24-2.74)$ & 0.003 \\
\hline $\mathrm{HDL}<40 \mathrm{M}<50 \mathrm{~F} \mathrm{mg} / \mathrm{dL}$ & $0.83(0.50-1.39)$ & 0.480 & $1.09(0.71-1.68)$ & 0.695 & $1.04(0.71-1.52)$ & 0.835 \\
\hline $\mathrm{LDL} \geq 100 \mathrm{mg} / \mathrm{dL}$ & $1.08(0.78-1.49)$ & 0.651 & $0.83(0.62-1.12)$ & 0.229 & $0.93(0.72-1.21)$ & 0.596 \\
\hline$B P \geq 140 / 85 \mathrm{mmHg}$ & $1.12(0.81-1.55)$ & 0.503 & $1.35(0.98-1.85)$ & 0.064 & $1.24(0.95-1.61)$ & 0.118 \\
\hline Non-proliferative retinopathy & $1.09(0.75-1.58)$ & 0.656 & $0.76(0.52-1.10)$ & 0.150 & $0.86(0.63-1.17)$ & 0.345 \\
\hline Proliferative retinopathy & $1.42(0.87-2.31)$ & 0.162 & $1.19(0.74-1.93)$ & 0.477 & $1.18(0.78-1.78)$ & 0.443 \\
\hline Lipid-lowering treatment & $0.87(0.61-1.25)$ & 0.464 & $0.85(0.59-1.22)$ & 0.370 & $0.87(0.65-1.18)$ & 0.373 \\
\hline Antihypertensive treatment & $1.31(0.90-1.90)$ & 0.155 & $1.23(0.86-1.77)$ & 0.256 & $1.21(0.90-1.65)$ & 0.211 \\
\hline Aspirin & $1.26(0.83-1.91)$ & 0.273 & $1.45(0.95-2.23)$ & 0.089 & $1.44(1.01-2.05)$ & 0.046 \\
\hline Insulin pump & $1.76(0.91-3.39)$ & 0.091 & $0.97(0.54-1.74)$ & 0.909 & $1.21(0.73-1.99)$ & 0.461 \\
\hline \multicolumn{7}{|l|}{ Separate models } \\
\hline Serum uric acid (mg/dL) & $1.07(0.96-1.20)$ & 0.211 & $1.04(0.94-1.16)$ & 0.460 & $1.04(0.95-1.15)$ & 0.393 \\
\hline Serum uric acid in the top quintile & $1.44(0.90-2.31)$ & 0.130 & $1.20(0.75-1.89)$ & 0.447 & $1.29(0.88-1.90)$ & 0.197 \\
\hline Smokers & $0.67(0.37-1.22)$ & 0.190 & $1.14(0.71-1.83)$ & 0.599 & $0.84(0.54-1.29)$ & 0.423 \\
\hline
\end{tabular}

Multivariate models were fitted including a missing indicator variable to indicate whether the BMI value is missing. Serum uric acid and smoking status evaluated in separate models that included patients with complete data

kidney damage and predictor of overt nephropathy in a small sample of patients with T1DM. Perkins and co-workers [15] several years later have shown among patients of the Joslin's T1DM cohort that GFR decline starts early in the course of microalbuminuria. Recent results from DCCT by Molitch and co-workers [21] have further confirmed the role of albuminuria in accelerating GFR loss among T1DM patients although a not trivial proportion of patients (i.e. 24\%), developed persistent eGFR $<60 \mathrm{ml} / \mathrm{min} / 1.73 \mathrm{~m} 2$ in absence of albuminuria [22]. The pathophysiology and clinical significance of normoalbuminuric renal impairment is a current matter of debate.

In our study, the role of mild eGFR reduction in predicting the progression of kidney function decline appears to be remarkable. In fact, patients with eGFR < $90 \mathrm{ml} / \mathrm{min} / 1.73 \mathrm{~m} 2$ show a constant and progressive increased risk to develop stage $\geq 3 \mathrm{CKD}$ as compared to patients with eGFR $>90 \mathrm{ml} / \mathrm{min} 1.73 \mathrm{~m} 2$; the former presented $80 \%$ increased risk to develop eGFR $<60 \mathrm{ml} /$ min for each $5 \mathrm{ml} / \mathrm{min}$ of eGFR decline. Although we've found that eGFR $<90 \mathrm{ml} / \mathrm{min} / 1.73 \mathrm{~m} 2$ is an independent predictor for low eGFR (i.e. eGFR $<60 \mathrm{ml} /$ $\mathrm{min} / 1.73 \mathrm{~m} 2$ ), when we looked at the eGFR loss $>30 \%$ than baseline, it seemed to be protective as compared to patient with eGFR $>90 \mathrm{ml} / \mathrm{min} / 1.73 \mathrm{~m} 2$ (Table 3). This finding is in line with data recently reported by Bjornstad and co-workers who studied a selected subset of 308 patients recruited from the Coronary Artery Calcification in Type 1 Diabetes $(N=210)$ and the Pittsburgh Epidemiology of Diabetes Complications studies $(N=98)$. The authors found that early renal function decline (defined as an annual loss of eGFR $\geq 3$ $\mathrm{ml} / \mathrm{min} / 1.73 \mathrm{~m} 2$ ), which is an independent predictor of overt nephropathy, was associated with greater baseline eGFR levels. This finding was consistent across the 
A

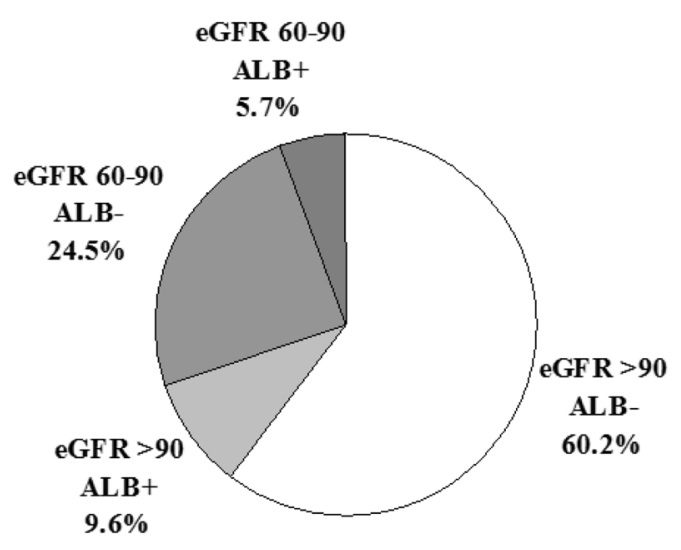

B

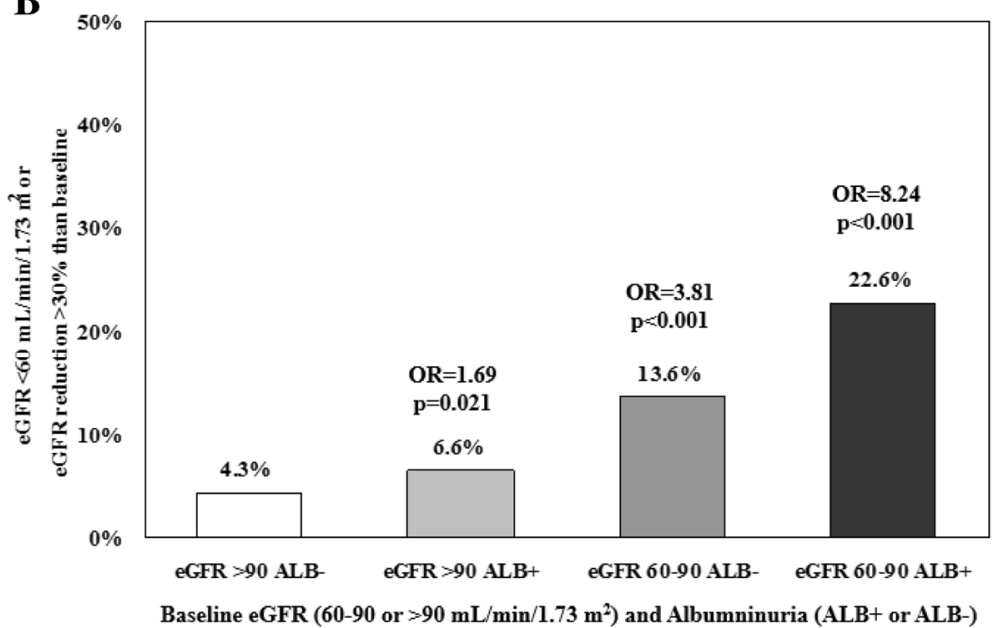

Fig. 3 a Study patients stratified by baseline eGFR (>90 mL/min/1.73 $\mathrm{m}^{2} / 60-90 \mathrm{~mL} / \mathrm{min} / 1.73 \mathrm{~m}^{2}$ ) and albuminuria (Alb+/Alb-); b Odd ratios of developing the composite renal endpoint over 4-year study period among different groups of patients

two samples studied by Authors [27]. With this regard, no effect of hyperfiltration on microalbuminuria development in patients with T1DM was reported by Ficociello and coworkers at Joslin Diabetes Center [28]. On the contrary, Chiarelli and co-workers found that hyperfiltration predicted microalbuminuria over a 10-year follow-up in children and young adults with T1DM [29]. Finally, a metaanalysis aiming to unravel the role of hyperfiltration on diabetic nephropathy onset, concluded that individual with hyperfiltration are at increased risk of progression to diabetic nephropathy [30]. However, most of the knowledge on the mechanisms of hyperfiltration on the kidney come from animal models [31]. In those studies, hyperfiltration produces an increased glomerular pressure and a reduced flow, both mechanisms starting kidney damage [32, 33]. Although the underlying pathophysiological mechanism linking hyperfiltration and kidney function loss is not completely understood, the role of increased intraglomerular pressure associated to hyperfiltration could have a significant role [34]. Indirect information coming from renal protective effect of new antihyperglycemic drugs such as sodium-glucose cotransporter-2 seem to support this view [35].

The risk of developing stage $\geq 3$ CKD was independent of albuminuria, although it raised significantly to 8.2 times when albuminuria was present. This finding emphasizes the significant and independent role of mild eGFR reduction in inducing $\geq 3$ CKD, even though the presence of albuminuria entails an adjunctive risk.

In line with our finding, Caramori and co-workers [8] have shown that normoalbuminuric patients with long-standing type 1 diabetes (particularly females with retinopathy and/or hypertension), with reduced measured GFR defined as $<90 \mathrm{ml} / \mathrm{min} / 1.73 \mathrm{~m} 2$, had worse diabetic glomerulopathy lesions than patients with similar duration of diabetes and normal or increased GFR, suggesting that careful GFR measurements may be indicated in normoalbuminuric patients, especially females with hypertension and retinopathy. 


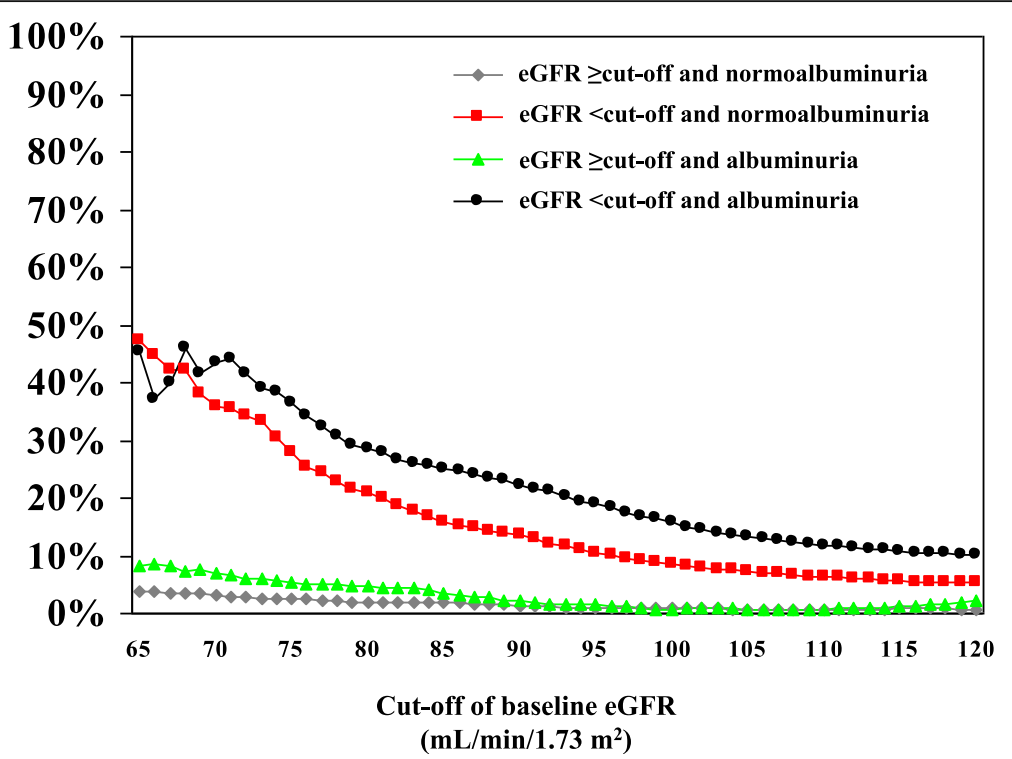

Fig. 4 Estimated worsening rate of renal function at any given baseline eGFR

Our study has limitations and strengths. Among the first ones, the follow-up duration is relatively short, although the mean age of patients (i.e. $45 \pm 14$ years) and long duration of disease (i.e. $18 \pm 12$ years) allowed us to develop significant number of renal events. Second, laboratory measures, including serum creatinine, were not measured in a single, centralized laboratory. This could lead to some variability (i.e. GFR). Moreover, albuminuria has been gathered only as a categorical trait, possibly contributing to variability of the outcome measure. Furthermore, follow-up data were available for the majority, but not all patients. Thus, the generalization of our findings should be cautious, as mortality from competitive risk was not positively collected in the missing subgroup.

On the other hand, the large sample-size and the homogeneous clinical features of patients, as well as the representative geographical distribution of the recruiting centers, contribute to a good representation of Italian real life clinical conditions.

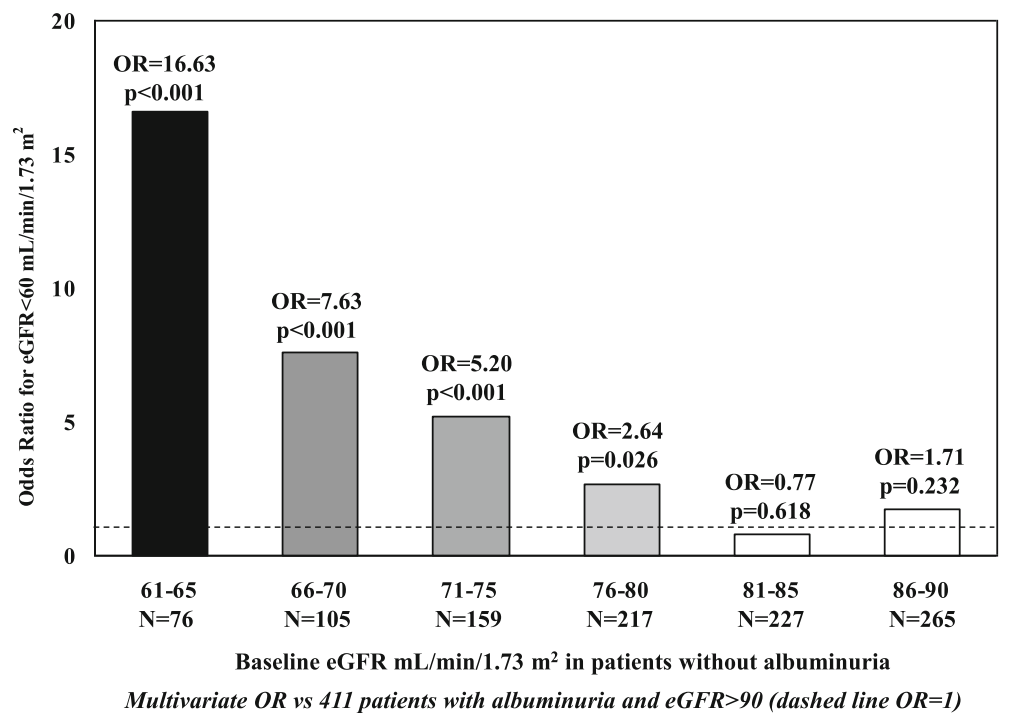

Fig. 5 Multivariate OR for the incidence of stage $\geq 3$ in patients with a given baseline eGFR and without albuminuria vs 411 patients with albuminuria and eGFR> 90 (dashed line $\mathrm{OR}=1$ ) 


\section{Conclusions}

Our data support the view that mild GFR reduction in patients with T1DM may be useful predictor of progression of GFR decline. Thus, microalbuminuria alone may not provide optimal identification of patients with T1DM at higher risk of renal impairment, measurements or estimation of GFR and identification of other risk factors will be surely useful.

\section{Additional files}

Additional file 1: Table S1. Clinical characteristics of patients at baseline and at 4-year grouped by of basal GFR. (DOCX $20 \mathrm{~kb}$ )

Additional file 2: Table S2. Baseline clinical characteristics of patients grouped by eGFR and albuminuria. (DOCX $19 \mathrm{~kb}$ )

\section{Abbreviations}

ACE-I: Angiotensin converting enzyme inhibitors; ACR: Albumin-to-creatinine ratio; AMD: Associazione Medici Diabetologi; ARB: Angiotensin receptor blocker; BMI: Body mass index; BP: Blood pressure; CKD: Chronic kidney disease; DCCT: Diabetes Control and Complications Trial; DKD: Diabetic kidney disease; ESRD: End-stage renal disease; GFR: Glomerular filtration rate; HbA1c: Glycated haemoglobin; HDL: High density lipoprotein; LDL: Low density lipoprotein; OR: Odds ratios; QoL: Quality of life; SD: Standard deviation; T1DM: Type 1 diabetes; T2DM: Type 2 diabetes; TG: Triglycerids

\section{Acknowledgements}

\section{AMD ANNALS Study Group:}

Editorial Board (in alphabetical order): Cimino Antonino', Fava Danila², Giorda Carlo Bruno ${ }^{3}$, Meloncelli Illidio ${ }^{4}$, Nicolucci Antonio ${ }^{5}$, Pellegrini Fabio ${ }^{5}$, Rossi Maria Chiara ${ }^{5}$, Turco Salvatore ${ }^{6}$, Vespasiani Giacomo ${ }^{4}$.

Statistical analysis and Coordinating centre: Pellegrini $F^{5}$, Graziano $G^{5}$, Lucisano $\mathrm{G}^{5}$, Memmo $\mathrm{R}^{5}$, Pellicciotta $\mathrm{E}^{5}$.

Affiliations: 'Spedali Civili, Diabetes Unit - Brescia; ${ }^{2}$ San Giovanni Addolorata Hospital, Diabetes and Metabolism Unit - Roma; ${ }^{3}$ ASL TO5, Diabets Unit Chieri (TO); ${ }^{4}$ Madonna del Soccorso Hospital, Diabets Unit - San Benedetto del Tronto (AP); ${ }^{5}$ Department of Clinical Pharmacology and Epidemiology, Consorzio Mario Negri Sud, Santa Maria Imbaro (CH).

Regional Tutors (in alphabetical order by region): Paciotti V, Pupillo M - Abruzzo; Armentano G, Giovannini C - Calabria; Armentano V, Laudato M, Turco S Campania; Acquati S, Ciardullo AV, Laffi G - Emilia Romagna; Felace G, Taboga C, Tortul C - Friuli Venezia Giulia; Santantonio G, Suraci C - Lazio; Ghisoni G, Raffa M - Liguria; Genovese S, Lovagnini-Scher CA, Rampini P, Rocca A, Ruggeri P - Lombardia; Tortato E, Cotti L - Marche; Cristofaro MR, Tagliaferri M - Molise; Comoglio M, Fornengo R - Piemonte; De Cosmo S, Gentile FM - Puglia; Gigante A, Mastinu F - Sardegna; Di Benedetto A, Pata P - Sicilia; Arcangeli A, Orsini P Toscana; Acler P, De Blasi G - Trentino Alto Adige; Cicioni G, Pocciati S - Umbria; Marangoni A, Nogara A - Veneto.

Participating centres (in alphabetical order by town): Lanero M, Bertero MG, Damassino R, Bergonzini C, Schumtz L, Seksich L - ACQUI TERME (AL); Pipitone A - ADRIA (RO); Boaretto M, Manfroi I, Parmesan L, Conte B, Soccol F - AGORDO (BL); Pagano A, Papini E, Rinaldi R,Petrucci L, Graziano F, Chianelli M, Silvagni S - ALBANO LAZIALE (RM); Rosco M - ALBEROBELLO (BA); Ansaldi E, Malvicino F, Battezzati M, Maresca P, Palenzona C ALESSANDRIA; Boemi M, Rabini RA, Brandoni G, Lanari L, Gatti C, Testa I ANCONA; Cherubini V - ANCONA;Doveri G, Pecorelli L, Ciccarelli A, Gallardini MB, Courthoud R, Sara Bredy S - AOSTA; Ricciardi GP - APRILIA (LT); Vitalone G, Setti D, Contrini P - ARCO (TN); Corsi A, Ghigliotti V, Oddone G, Ponzani P, Valbonesi G - ARENZANO (GE); Mazzini V - ARGENTA (FE); Di Berardino P, Colleluori P, Montani V, Trosini V - ATRI (TE); Velussi M - AURISINA (TS); Paciotti V, Alfidi P, Verdecchia B, Baliva L, Di Pietro A, Franchi G, Luce RP AVEZZANO (AQ); Marangoni A, Pianta A, Ferrari M, Balzano S, Beltranello G BASSANO DEL GRAPPA (VI); Dal Fabbro S, Aricò CN, Cervo L, Zanon R, Rossa S - BELLUNO; Rosco M, Di Pace MC - BISCEGLIE (BAT); Laffi G, Ciavarella A, Giangiulio S, Grimaldi M, Mustacchio A, Santacroce G - BOLOGNA S. ORSOLA MALPIGHI; Fattor B, Monauni T, Cristini M, Orion G, Crazzolara D, Amor F, Eisath JE, Lintner S - BOLZANO; Garavelli S, Calari T, Marini P, Sandri O, Scala
M, Stroppa C, Trentin A - BORGO VALSUGANA (TN); Garavelli S, Calari T, Marini P, Carlin R, Carli B, Sandonà M - BORGO VALSUGANA (TN); Garavelli S, Calari T, Marini P, Zortea C, Bonet L, Pradel L, Reato S - BORGO VALSUGANA (TN); Buschini M, Bonfiglioli D, Mones D, Beldì F - BORGOMANERO (NO); Morea A, Bondesan L, Perbellini S - BOVOLONE (VR); Cimino A, Valentini U, Agosti B, Corsini R, Girelli A, Zarra E, Rocca L - BRESCIA; De Blasi G, Bergmann M, Pradi I, Unterkircher S, Piok M, Pichler M - BRESSANONE (BZ); Trinchera A, Palamà G, Palma P - BRINDISI; Carboni L, Murtas MG, Mudadu T, Turco MP, Floris M, Delogu A, Farris L - CAGLIARl; Songini M, Piras G, Seguro R, Floris R, Corona G, Lai M, Piras E - CAGLIARI; Contini PP, Cocco S, Pilosu RM, Sannia MC, Spanu F - CAGLIARI; Busciantella Ricci N, Cartechini MG, Agostinelli G, Fiorelli C - CAMERINO(MC); Nuzzi A, Ballauri C - CANALE (CN); Giorda CB, Lesina A, Romeo F - CARMAGNOLA (TO); Ciardullo AV, Giudici G, Maciejewska EG, Deroma A, Paduano M, Rossi L, Vagnini C - CARPI (MO); Dolci M, Mori M, Baccetti F, Gregori G - CARRARA (MS); Straface E CASALBORDINO (CH); Pozzuoli G, Laudato M, Barone M, Stasio GB CASERTA; Tondini S, Borgoni F - CASTEL DEL PIANO (GR); Grosso J, Rossi L, Scarsellato C, Sciulli A, De Marco F - CASTEL DI SANGRO (AQ); Confortin L, Marin N, Lamonica M - CASTELFRANCO (TV); Gialdino S - CASTROVILLARI (CS); Borzì V, Gatta C, Rapisard R, Strano S, Calabrò M - CATANIA; Puccio L CATANZARO; Zolli M, Coracina A - CAVARZERE (VE); Starnone V, Del Buono A, Terracciano AM - CELLOLE (CE); Monda MV - CENTO (FE); Castro F, Guaglianone A, Maccari V - CETRARO (CS); Corsi L, Versari G, Falivene MR, Boletto N, Corsi S - CHIAVARI (GE); Giorda CB, Marafetti L - CHIERI (TO); Vitacolonna E, Capani F, Caputo L, Di Nisio L, Simonetti F - CHIETI; Boscolo Bariga A, Nogara A, Ballarin G, De Boni S, Di Benedetto S - CHIOGGIA (VE); Chiambretti AM, Fornengo R, Di Vito L, Pascuzzo MD, Urli P - CHIVASSO (TO); Rocca A, Rumi P, Balzarini B, Galli P, Castellan M, Giannetti A, Russotti C, De Blasi A, Perna A - CINISELLO BALSAMO (MI); Campanelli C, Ranchelli A, Biccheri D, Dadi G - CITTA' DI CASTELLO (PG); Santantonio G, Massa L, Baldi GP, Sciacca F, Costanzo E, Spada M, Paolini G - CIVITAVECCHIA (RM); Ziller P, Portolan F, Pasolini G - CLES (TN); Ghilardi G, Fiorina P - CLUSONE (BG); Grata ML - CODIGORO (FE); Capretti L, Speroni G, Fugazza L - CODOGNO (LO); Massafra C, Lovagnini Scher A - COLOGNO MONZESE (MI); Cimicchi MC, Percudani C, Risolo T, Saccò P - COLORNO (PR); Grata ML - COMACCHIO (FE); Gidoni Guarnieri GL, Piccolo D, Bravin C, De Noni E, Scarpel M, Marcon M, Giacon F - CONEGLIANO (TV); Panebianco G, Tadiotto F, Da Tos V, D’Ambrosio M - CONSELVE (PD); Pellizzola D, Zampini MA, Frezzati E, Mari E, Raminelli E - COPPARO (FE); Gaiti D, Bosi EA, Chierici G, Pilla S, Copelli M, Zanichelli P, Bertelli L, Caretta P, Vezzani V, Bodecchi S - CORREGGIO (RE); Longobucco A - COSENZA; Ruggeri P, Di Lembo S, Spotti E, Carrai E, Degli Innocenti A, Manini L, Persico R, Rossi C - CREMONA; Magro G - CUNEO; Marelli G, Vilei V, Andrioli M, Bellato L, Fedeli M, Merlini A, Pinelli G - DESIO (MI); Marin G, Contin ML, Gallo A, Parlato P, Pecchielan W, Jacovacci J DOLO (VE); Placentino G - DOMODOSSOLA (VB); Richini D, Molinari S, Strazzeri R - ESINE (BS); Panebianco G, Tadiotto F, Da Tos V, D'Ambrosio M ESTE (PD); Fabbri T, Di Bartolo P - FAENZA (RA); Cotti L, Garrapa G - FANO (PU); D'Incau F, Lagomanzini P, Conte P, Todesco F - FELTRE (BL); Foglini P, Tortato E, Pantanetti P, Bedetta C, Maricotti R - FERMO; Tomasi F, Monesi M, Graziani R, Beretta F, Penna L - FERRARA; Guberti A, Dazzi D - FIDENZA (PR); Dolci M, Mori M, Baccetti F, Gregori G - FIVIZZANO (MS); Pocciati S FOLIGNO (PG); Forte E, Gasbarrone A, Marrocco T, Moschetta R - FONDI (LT); Tuccinardi F, De Meo F, Forte E, Coppola A, Pirolozzi P, Placitelli E, Vallefuoco R - GAETA (LT); Taboga C, Catone B, Ceschia S, Urban M - GEMONA DEL FRIULI (UD); Ghisoni G, Fabbri F, Torresani M, Crovetto R - GENOVA; Corsi A, Battistini M, Fabbri F, Carosia P - GENOVA; Viviani GL, Durante A, Pais F, Lilliu V - GENOVA; Rosco M, Quieto C - GIOIA DEL COLLE (BA); D'Ugo E,

Squadrone M, Amenduni T, lovannisci MM, Della Penna L, Potente F, Delle Donne T, Massa C, Ulisse MA - Gissi (CH); De Berardinis S, Guarnieri I, Pace S, Splendiani M, Di Giuseppe R - GIULIANOVA (TE); Tortul C, Brunato B, Assaloni R, Muraro R, Loro R, Bucciol S - GORIZIA; Rosco M, Lavacca C - GRAVINA (BA); Rossi M, Sabbatini G, Quadri F, Sambuco L, Santacroce C - GROSSETO; Bosi EA, Chierici G, Pilla S, Gaiti, Copelli, Zanichelli, Bertelli, Paola Caretta D, Vezzani V, Bodecchi S - GUASTALLA (RE); Marino C, Micheletti A, Petrelli A GUBBIO (PG); Corda A, Pisano L, Guaita G, Deias C - IGLESIAS (CI); Trevisan G, Coletti I - JESOLO (VE); lannarelli R - L'AQUILA; Pupillo M, De Luca A, Minnucci A, Antenucci D, Di Florio C, Angelicola G, Bosco A, Fresco R, Di Marco G - LANCIANO (CH); Ugolotti D, Cadossi T, Ferrari M - LANGHIRANO (PR); Tagliaferri M, Di Caro P, Mazzocchetti M - LARINO (CB); Buzzetti R, Leto G, Gnessi C, Cipolloni L, Foffi C, Moretti C, Venditti C - LATINA; Morea A, Bondesan L, Perbellini S - LEGNAGO (VR); Meniconi R, Bertoli S, Cosimi S - 
LIDO DI CAMAIORE (LU); Di Cianni G, Orsini P, Turco A, Richini A, Marconi S, Sannino C, Lemmi P, Giuntoli S, Manfrè N - LIVORNO; Giannini F, di Carlo A, Casadidio I - LUCCA; Melandri P, Di Bartolo P - LUGO (RA); Maolo G, Polenta B, Piccinini N - MACERATA; Pozzuoli G, Laudato M, Barone M, Stasio GB MADDALONI (CE); Vincenti C, Pastore N, Mega P, Magurano E, Cananiello A MAGLIE (LE); Francescutto CA, Brussa Toi E, Gaspardo G, Angeli L, Ronchese L - MANIAGO (PN); Sciangula L, Ciucci A, Contartese A, Banfi E, Castelli E MARIANO COMENSE (CO); Tatti P, Bloise D, Di Mauro P, Masselli L - MARINO (RM); Lo Presti A, Scarpitta AM, Gambina F - MARSALA (TP); Venezia A, Morea R, Lagonigro G, Copeta G, lannucci V, Milano V, Trupo M - MATERA; Lochmann A, Marchetto PE, Incelli G, De Paola G, Steiger MM, Gamper MA, Breitenberger S, Holzner M, Frischmann J - MERANO (BZ); Lambiase C, Di Vece T, D'Aniello M, Fezza M, Giordano C, Leo F - MERCATO S. SEVERINO (SA);Saitta G - MESSINA; Di Benedetto A, Cucinotta D, Di Vieste G, Pintaudi B - MESSINA; Pata P, Mancuso T - MESSINA; Musacchio N, Giancaterini A, Lovagnini Scher A, Pessina L, Salis G, Schivalocchi F - MILANO; Testori G, Rampini PA, Cerutti N, Morpugo PS, Cavaletto ML, Bonino G, Morreale F MILANO; Mariani G, Ragonesi PD, Bollati P, Colapinto P - MILANO; Bosi E, Falqui L - MILANO; Bortolato L, Cosma A, Pistolato P, Centenaro B, Ceccato A; MIRANO (VE); Campobasso G - MODUGNO (BA); Gentile FM, Zaurino F, Mazzotta G - MOLA DI BARI (BA); Comoglio M, Manti R, Giorda CB MONCALIERI (TO); Tortul C, Da Ros R, Carlucci S, Narduzzi L, Bortolotto D, D'Acunto L, Stanic L, Brunato B, Assaloni R - MONFALCONE (GO); Volpi A, Coracina A, Cospite AM - MONTEBELLUNA (TV); Manicardi V, Michelini M, Finardi L, Borghi F, Manicardi E - MONTECCHIO EMILIA (RE); Lombardi S, Tommasi C, laccarino M, Cozza S, Binotto M, Marini F, Mecenero I, Massignani S, Stecco P, Urbani E, Massariol W, Parolin R - MONTECCHIO MAGGIORE (VI); Gatti A, Bonavita M, Creso E, Giannettino R, Gobbo M - NAPOLI; Turco S, lovine C, Turco AA, Riccardi G - NAPOLI; lazzetta N, Giannattasio C - NAPOLI; Armentano V, Egione O, Galdieri S, Velotti A, Azzolina A, Annicelli G NAPOLI; Sorrentino T, Gaeta I, Del Buono A - NAPOLI; Zenari L, Bertolini L, Sorgato C, Grippaldi F - NEGRAR (VR); Stroppiana M, Popolizio R, Carbone N, Grasso S, Abate S, Gaggero GC - NIZZA MONFERRATO (AT); Strazzabosco M, Brun E - NOVENTA VICENTINA (VI); Carlesi GP, Garrone S - NOVI LIGURE (AL); Gigante A, Cicalò AM, Clausi C, Cau R - NUORO; Manconi A, Carboni A, Angius MF, Pinna AA, Caria S, Filigheddu GD, Tonolo G, Carta I - OLBIA (OT); Calebich S, Burlotti C - OME (BS); Saglietti G, Placentino G, Schellino A OMEGNA (VB);Mastinu F, Madau G, Cossu M, Mulas F, Zoccheddu S ORISTANO; Balsanelli M, Fetonti M, Rotolo A, Sambo P - OSTIA (RM); Secchi E, Angotzi MA, Loddoni S, Brundu I, Careddu F, Becciu A, Gabriella Piras G OZIERI (SS); Novara F, Cipro F - PACECO (TP); Torchio G, Palumbo P, Bianchi A, Colucci G, La Motta G - PADERNO DUGNANO (MI); Tiengo A, Avogaro A, Bruttomesso D, Crepaldi C, Fadini G, Guarnieri G, Lavagnini MT, Maran A, Vedovato M, de Kreutzenberg V - PADOVA; Fedele D, Lapolla A, Sartore G, Bax G, Cardone C, Dalfrà MG, Masin M, Toniato R, Francesco Piarulli PADOVA; Mattina G - PALERMO; Fulantelli MA - PALERMO; Gioia D, Conti M - PALERMO; Ridola G - PALERMO; D’Agati F - PALERMO; Grossi G, De Berardinis F - PAOLA (CS); Zavaroni I, Dei Cas A, Franzini L, Usberti E, Antonimi M, Anelli N, Poli R, Ridolfi V, Michela M, Haddoub S, Prampolini G, Muoio A - PARMA; Cimicchi MC, Ugolotti D, Filippi D, Ferrari M, Bucci F PARMA; Tardio SM, Calderini MC, Magotti MG, Quarantelli C, Vernazza MA, Carolfi A, Saracca R - PARMA; Picchio E, Del Sindaco P - PERUGIA; Spalluto A, Maggiulli L, Torreggiani V, Rastelletti S, Ugolini C, Pucci N, Magi S, Muratori S - PESARO; La Penna G, Consoli A - PESCARA; Galeone F, Magiar AV - PESCIA (PT); Gherardini V, Moretti L, Bientinesi M, Landi L, Bernardi A - PIOMBINO (LI); Del Prato S, Miccoli R, Bianchi C, Penno G, Venditti F - PISA; Anichini R, De Bellis A, Bruschi T, Butelli L, Gioffredi M, Gori R, Picciafuochi R, Malagoli R, Bernini A - PISTOIA; Gelisio R, Zanon M, Del Bianco A, Bamiston A, Signorato M - PORTOGRUARO (RO); Mazzini V - PORTOMAGGIORE (FE); Citro G POTENZA; Arcangeli A, Calabrese M, lanni L, Lorenzetti M, Marsocci A, Guizzotti S, Memoli G - PRATO; Cabasino F, Farci F, Atzori A, Sanna A, Ghiani M, Siotto I, Sedda M, Manis A, Loddo C, Loddo I, Pisano L, Seguro P, Cuomo A, Orlando L, Olanda GB - QUARTU SANT'ELENA (CA); Pucci A -

QUATTROMIGLIA DI RENDE (CS); Massenzo M - QUATTROMIGLIA DI RENDE (CS); Di Bartolo P, Sardu C - RAVENNA; Giovannini C - REGGIO CALABRIA; Perrone G, Corazziere F, La Puzza I - REGGIO CALABRIA; Tripodi PF, Riggio S, Giampaolo A - REGGIO CALABRIA; Mannino D - REGGIO CALABRIA; Aleandri AR, Guidi MV, Battisti B, Faraglia MR, Lilli V - RIETI; Leotta S, Suraci C, Visalli N,
Gagliardi A, Fontana L, Altomare M, Carletti S, Abbruzzese S - ROMA; Chiaramonte F, Giordano R, Rossini M, Migneco G - ROMA; Cappelloni D, Urbani A - ROMA; Piergiovanni F, Fava D, Simonetta A, Massimiani F ROMA; Bulzomì R - ROMA; Giuliano M, Pennafina MG, Di Perna P - ROMA; D'Accinni MP, Paolucci D, D'Ubaldi A, D'Angelo MT, Masaro G, Pietrantoni M, Fratini M, La Rosa R - ROMA; Poggi M, Piccirilli F, Pisano R, Saponara C, Conforti I, Penza A - ROMA; Scalpone R, Lo Pinto S, lacovella L, Caccamo C, Sposito S, Teodonio C - ROMA; Armentano G, Restuccia MG, Mirto G ROSSANO (CS); Girardello R, Gennaro R, De Moliner L, Bettini E, Mattuzzi A, Speese K, Frisinghelli F - ROVERETO (TN); Genovese S, Locatelli F - Rozzano (MI); Nicoletti M, Trojan N, Centis R - S.VITO AL TAGLIAMENTO (PN); Li Volsi P, Levis E, Zanette G - SACILE (PN); Comba G, Ballatore L - SALUZZO (CN); Cattaneo A, Aglialoro A, Guido R, Patrone M, Zecchini M - SAMPIERDARENA (GE); Vespasiani G, Meloncelli I, Clementi L, Galetta M, Marconi V - SAN BENEDETTO DEL TRONTO (AP); Bordin P, Perale L - SAN DANIELE DEL FRIULI (UD); Vinci C, Sira Zanon M, Geretto L, Toffolo C, Furlan MG, Mazzanti G SAN DONÀ DI PIAVE (VE); Vinci M, Gelisio R - SAN DONA' DI PIAVE (VE); Sica V, Armeni M, Derai R, Ennas O, Mamusa S, Pisano MA, Carreras L - SAN GAVINO MONREALE (SV); De Cosmo S, Rauseo A - SAN GIOVANNI ROTONDO (FG); Cervone S, Leggieri A, Pontonio M - SAN MARCO IN LAMIS (FG); Sturaro R, Raffa M, Quattrocchi F, Molinaro M, Trasatti M, Ferretti B - SANREMO (IM); Rosco M, Labarile G - SANTERAMO (BA); Baule GM, Gentilini A, Spanu MA, Fancellu A, Bianco P - SASSARI; Lione L, Massazza G, Bocchio G, Bosco E SAVONA; Monachesi M, Carta G, Boschetti M, Ceresola E, Venier E - SAVONA; Calcaterra F, Cataldi F, Miola M - SCHIO(VI); Manfrini S - SENIGALLIA(AN); Lai A, Locci B, Putzu D - SENORBI (CA); Tanganelli I, Leonini M - SIENA; Egger K, Marchiotto W - SILANDRO (BZ); Vincis L, Orlandini V, Pilloni C, Farci R, Pelligra I, Renier G - SIRAI - CARBONIA; Mameli M, Pala A, Devigus E - SORGONO (NU); Felace G, Fumagalli I - SPILIMBERGO (PN); Lalli C, Leandri M, Agliani M, De Pascalis L - SPOLETO (PG); Malci F, De Ciocchis A - SUBIACO (RM); Diodati MB, Macerola B - SULMONA (AQ); Davì S, Caccavale A, Brocato L, Pognant Gros M, Borla S - SUSA (TO); Lattanzi E, Piersanti C, Piersanti A, Spinelli I, Tuzzoli L, Tulini V, Quaranta G, lorio V, Tirabovi M - TERAMO; De Candia - TERLIZZI (BA); Cicioni G, Massarelli MG, Venturi S - TERNI; Travaglini A, Draghi P - TERNI; Pomante P - TOCCO DA CASAURIA (PE); Richiardi L, Clerico A - TORINO; Bruno A, Cavallo Perin P, Ghigo E, Porta M, Scuntero P, Arcari R, Bertaina S, Bo S, Broglio F, Bruno G, Degiovanni M, Fornengo P, Grassi G, Inglese V, Maccario M, Maghenzani G, Marena S, Martina V, Passera P, Ruiu G, Tagliabue M, Zanone M - TORINO; Monge M, Boffano GM, Macrì $K$, Maio P - TORINO; Ozzello A, Pergolizzi E, Gaia D, Gennari P, Micali G, Rossetto E, Dalmazzo C, Oreglia M, Stefani T - TORINO; Dossena C, Paglia P, Bosoni S - TORTONA (AL); Acler P, Romanelli T, Inchiostro S, Dauriz M TRENTO; Bossi CA, Meregalli G, Balini A, Berzi D, Filippini B, Crotto G TREVIGLIO (BG); Paccagnella A, Orrasch M, Sambataro M, Citro T, Kiwanuka E, Bagolin E, Almoto B - TREVISO; Macchia A, Branca MT, Filesi M - TRICASE (LE); Candido R, Caroli E, Manca E, Petrucco A, Tommasi E, Jagodnik G, Baskar B, Daris N, Dal Col P - TRIESTE; Pellegrini MA, Tonutti L, Venturini G - UDINE; Andreani M, Turchi F, Fedrighelli F, Martinelli G - URBINO; Sposito S, Rongioletti R, Candidi M - VELLETRI (RM); Pais M, Moro E - VENEZIA; Cervellino F, Sinisi R, Zampino A - VENOSA (PZ); Saglietti G, Placentino G, Schellino A - VERBANIA PALLANZA (VB); Mingardi R, Lora L, Reitano R, Stocchiero C - VICENZA; Strazzabosco M, Brun E, Simoncini M, Mesturino CA, Zen F - VICENZA; Di Pietro S, Scoponi C, Tilaro L, Pelliccioni S, Slongo R, Vita E; VITERBO; Garofalo A, Vitale F, Campanella B - VITTORIA (RG); Mastrilli V, Del Buono A, Borrelli T, D'Avino A - VOLLA (NA); Morea A, Perbellini A, Bondesan $L-$ ZEVIO (VR).

\section{Funding}

none.

\section{Availability of data and materials}

The datasets used during the current study are available from the corresponding author on reasonable request.

\section{Authors' contributions}

AM, FV, PF, CG, AC, GR, PG, RP and SDC made substantial contributions to conception, design, acquisition of data, analysis and interpretation of data. All Authors have been involved in drafting the manuscript and revising it 
critically for important intellectual content. All Authors gave final approval of the version to be published.

\section{Ethics approval and consent to participate}

Ethics approval and informed consent to participate was not required given that the automated anonymized database precludes identification of individual patients (Linee guida per i trattamenti di dati personali nell'ambito delle sperimentazioni cliniche di medicinali - 24 luglio 2008 - G.U. n. 190 del 14 agosto 2008 - Guidelines for Personal Data Processing in Clinical Trials of Medicines - July 24, 2008 - Official Gazette n. 190, August 14, 2008).

\section{Consent for publication}

Not applicable.

\section{Competing interests}

The authors declare that they have no competing interests.

\section{Publisher's Note}

Springer Nature remains neutral with regard to jurisdictional claims in published maps and institutional affiliations.

\section{Author details}

${ }^{1}$ Department of Medical Sciences, Scientific Institute "Casa Sollievo della Sofferenza", IRCCS Casa Sollievo della Sofferenza, v.le Cappuccini, 71013 San Giovanni Rotondo, FG, Italy. ${ }^{2}$ Department of Internal Medicine, University of Genoa and Policlinico San Martino, Genova, Italy. ${ }^{3}$ Department of Medicine, University of Padova, Padova, Italy. ${ }^{4}$ Diabetes and Metabolism Unit ASL Turin 5, Chieri, Italy. Institut d'Investigacions Biomèdiques August Pii Sunyer (IDIBAPS) and Centro de Investigación Biomédicaen Red de Diabetes y Enfermedades Metabólicas Asociadas (CIBERDEM), Barcelona, Spain. ${ }^{6}$ U.O. Diabetologia e Malattie Metaboliche, Multimedica IRCCS, Sesto San Giovanni, Milan, Italy. ${ }^{7}$ Department of Clinical and Experimental Medicine, University of Messina, Messina, Italy. ${ }^{8}$ Associazione Medici Diabetologi, Rome, Italy. ${ }^{9}$ Department of Internal Medicine, University of Genoa and Policlinico San Martino, Genova, Italy.

Received: 1 September 2017 Accepted: 13 November 2018 Published online: 04 December 2018

\section{References}

1. Radcliffe NJ, Seah JM, Clarke M, Maclsaac RJ, Jerums G, Ekinci El. Clinical predictive factors in diabetic kidney disease progression. J Diabetes Investig. 2017:8(1):6-18

2. Valmadrid $C T$, Klein R, Moss SE, Klein BE. The risk of cardiovascular disease mortality associated with microalbuminuria and gross proteinuria in persons with older-onset diabetes mellitus. Arch Intern Med. 2000;160(8):1093-100.

3. Krolewski AS. Progressive renal decline: the new paradigm of diabetic nephropathy in type 1 diabetes. Diabetes Care. 2015;38(6):954-62.

4. Marshall SM. Natural history and clinical characteristics of CKD in type 1 and type 2 diabetes mellitus. Adv Chronic Kidney Dis. 2014;21(3):267-72.

5. Abdel-Kader K, Myaskovsky L, Karpov I, Shah J, Hess R, Dew MA, Unruh M. Individual quality of life in chronic kidney disease: influence of age and dialysis modality. Clin J Am Soc Nephrol. 2009;4(4):711-8.

6. Pacilli A, Viazzi F, Fioretto P, Giorda C, Ceriello A, Genovese S, Russo G, Guida P, Pontremoli R, De Cosmo S. AMD-Annals study group. Epidemiology of diabetic kidney disease in adult patients with type 1 diabetes in Italy: the AMD-Annals initiative. Diabetes Metab Res Rev. 2017; 33(4). https://doi.org/10.1002/dmrr.2873.

7. Parving $\mathrm{HH}$, Persson F, Rossing P. Microalbuminuria: a parameter that has changed diabetes care. Diabetes Res Clin Pract. 2015;107(1):1-8.

8. Caramori ML, Fioretto P, Mauer M. Low glomerular filtration rate in normoalbuminuric type 1 diabetic patients: an indicator of more advanced glomerular lesions. Diabetes. 2003;52(4):1036-40.

9. Piscitelli P, Viazzi F, Fioretto P, Giorda C, Ceriello A, Genovese S, Russo G, Guida P, Pontremoli R, De Cosmo S. Predictors of chronic kidney disease in type 1 diabetes: a longitudinal study from the AMD Annals initiative. Sci Rep. 2017;7(1):3313.

10. Penno G, Russo E, Garofolo M, Daniele G, Lucchesi D, Giusti L, Sancho Bornez V, Bianchi C, Dardano A, Miccoli R, Del Prato S. Evidence for two distinct phenotypes of chronic kidney disease in individuals with type 1 diabetes mellitus. Diabetologia. 2017;60(6):1102-13.
11. Pezzolesi MG, Poznik GD, Mychaleckyj JC, Paterson AD, Barati MT, Klein JB, Ng DP, Placha G, Canani LH, Bochenski J, Waggott D, Merchant ML, Krolewski B, Mirea L, Wanic K, Katavetin P, Kure M, Wolkow P, Dunn JS, Smiles A, Walker WH, Boright AP, Bull SB, DCCT/EDIC Research Group, Doria A, Rogus JJ, Rich SS, Warram JH, Krolewski AS. Genome-wide association scan for diabetic nephropathy susceptibility genes in type 1 diabetes. Diabetes. 2009;58(6):1403-10.

12. Sandholm N, Van Zuydam N, Ahlqvist E, Juliusdottir T, Deshmukh HA, Rayner NW, Di Camillo B, Forsblom C, Fadista J, Ziemek D, Salem RM, Hiraki LT, Pezzolesi M, Trégouët D, Dahlström E, Valo E, Oskolkov N, Ladenvall C, Marcovecchio ML, Cooper J, Sambo F, Malovini A, Manfrini M, McKnight A, Lajer M, Harjutsalo V, Gordin D, Parkkonen M, FinnDiane Study Group, Tuomilehto J, Lyssenko V, McKeigue PM, Rich SS, Brosnan MJ, Fauman E, Bellazzi R, Rossing P, Hadjadj S, Krolewski A, Paterson AD, DCCT/EDIC Study Group, Florez JC, Hirschhorn JN, Maxwell AP, GENIE consortium, Dunger D, Cobelli C, Colhoun HM, Groop L, MI MC, Groop PH, SUMMIT consortium. The genetic landscape of renal complications in type 1 diabetes. J Am Soc Nephrol. 2017;28(2):557-74.

13. Hovind P, Tarnow L, Rossing P, Jensen BR, Graae M, Torp I, Binder C, Parving $\mathrm{HH}$. Predictors for the development of microalbuminuria and macroalbuminuria in patients with type 1 diabetes: inception cohort study. BMJ. 2004;328(7448):1105.

14. Feodoroff M, Harjutsalo V, Forsblom C, Thorn L, Wadén J, Tolonen N, Lithovius $\mathrm{R}$, Groop PH. Smoking and progression of diabetic nephropathy in patients with type 1 diabetes. Acta Diabetol. 2016;53(4):525-33.

15. Perkins BA, Ficociello LH, Ostrander BE, Silva KH, Weinberg J, Warram JH, Krolewski AS. Microalbuminuria and the risk for early progressive renal function decline in type 1 diabetes. J Am Soc Nephrol. 2007;18(4):1353-61.

16. De Cosmo S, Rossi MC, Pellegrini F, Lucisano G, Bacci S, Gentile S, Ceriello A, Russo G, Nicolucci A, Giorda C, Viazzi F, Pontremoli R, AMD-Annals Study Group. Kidney dysfunction and related cardiovascular risk factors among patients with type 2 diabetes. Nephrol Dial Transplant. 2014;29(3):657-62.

17. De Cosmo S, Viazzi F, Pacilli A, Giorda C, Ceriello A, Gentile S, Russo G, Rossi MC, Nicolucci A, Guida P, Feig D, Johnson RJ, Pontremoli R, AMD-Annals Study Group. Serum uric acid and risk of CKD in type 2 diabetes. Clin J Am Soc Nephrol. 2015;10(11):1921-9.

18. Nicolucci A, Rossi MC, Arcangeli A, Cimino A, de Bigontina G, Fava D, Gentile S, Giorda C, Meloncelli I, Pellegrini F, Valentini U, Vespasiani G, AMD-Annals Study Group. Four-year impact of a continuous quality improvement effort implemented by a network of diabetes outpatient clinics: the AMD-Annals initiative. Diabet Med. 2010;27(9):1041-8.

19. Viazzi F, Piscitelli P, Giorda C, Ceriello A, Genovese S, Russo GT, Fioretto P, Guida P, De Cosmo S, Pontremoli R, AMD-Annals Study Group. Association of kidney disease measures with risk of renal function worsening in patients with hypertension and type 2 diabetes. J Diabetes Complicat. 2017;31(2):419-26.

20. Levey AS, Stevens LA, Schmid CH, Zhang YL, Castro AF 3rd, Feldman HI, Kusek JW, Eggers P, Van Lente F, Greene T, Coresh J. CKD-EPI (chronic kidney disease epidemiology collaboration). A new equation to estimate glomerular filtration rate. Ann Intern Med. 2009;150(9):604-12.

21. Wu HY, Peng YS, Chiang CK, Huang JW, Hung KY, Wu KD, Tu YK, Chien KL. Diagnostic performance of random urine samples using albumin concentration vs ratio of albumin to creatinine for microalbuminuria screening in patients with diabetes mellitus: a systematic review and meta-analysis. JAMA Intern Med. 2014;174(7):1108-15.

22. Molitch ME, Steffes $M$, Sun $W$, Rutledge $B$, Cleary $P$, de Boer $\mid H$, Zinman B, Lachin J. Epidemiology of diabetes interventions and complications study group. Development and progression of renal insufficiency with and without albuminuria in adults with type 1 diabetes in the diabetes control and complications trial and the epidemiology of diabetes interventions and complications study. Diabetes Care. 2010;33(7):1536-43.

23. de Boer $\mathrm{IH}$, Afkarian M, Rue TC, Cleary PA, Lachin JM, Molitch ME, Steffes MW, Sun W, Zinman B. Diabetes control and complications trial/ epidemiology of diabetes interventions and complications (DCCT/EDIC) research group. Renal outcomes in patients with type 1 diabetes and macroalbuminuria. J Am Soc Nephrol. 2014;25(10):2342-50.

24. Costacou T, Ellis D, Fried L, Orchard TJ. Sequence of progression of albuminuria and decreased GFR in persons with type 1 diabetes: a cohort study. Am J Kidney Dis. 2007;50(5):721-32.

25. Bjornstad P, Pyle L, Kinney GL, Rewers M, Johnson RJ, Maahs DM, Snell-Bergeon JK. Adiponectin is associated with early diabetic kidney 
disease in adults with type 1 diabetes: a coronary artery calcification in type 1 diabetes (CACTI) study. J Diabetes Complicat. 2017;31(2):369-74.

26. Viberti GC, Hill RD, Jarrett RJ, Argyropoulos A, Mahmud U, Keen H. Microalbuminuria as a predictor of clinical nephropathy in insulindependent diabetes mellitus. Lancet. 1982;1(8287):1430-2.

27. Bjornstad P, Costacou T, Miller RG, Maahs DM, Rewers MJ, Orchard TJ, Snell-Bergeon JK. Predictors of early renal function decline in adults with type 1 diabetes: the coronary artery calcification in type 1 diabetes and the Pittsburgh epidemiology of diabetes complications studies. Diabet Med. 2017;341:1532-40.

28. Ficociello LH, Perkins BA, Roshan B, Weinberg JM, Aschengrau A, Warram $\mathrm{JH}$, Krolewski AS. Renal hyperfiltration and the development of microalbuminuria in type 1 diabetes. Diabetes Care. 2009;32(5):889-93.

29. Chiarelli F, Verrotti A, Morgese G. Glomerular hyperfiltration increases the risk of developing microalbuminuria in diabetic children. Pediatr Nephrol. 1995;9:154-8.

30. Magee GM, Bilous RW, Cardwell CR, Hunter SJ, Kee F, Fogarty DG. Is hyperfiltration associated with the future risk of developing diabetic nephropathy? A meta-analysis. Diabetologia. 2009;52:691-7.

31. Levine DZ. Can rodent models of diabetic kidney disease clarify the significance of early hyperfiltration? Recognizing clinical and experimental uncertainties. Clin Sci (Lond). 2008:114:109-18.

32. Brenner BM, Meyer TW, Hostetter TH. Dietary protein intake and the progressive nature of kidney disease: the role of hemodynamically mediated glomerular injury in the pathogenesis of progressive glomerular sclerosis in aging, renal ablation, and intrinsic renal disease. N Engl J Med. 1982;307:652-9.

33. Brenner BM. Hemodynamically mediated glomerular injury and the progressive nature of kidney disease. Kidney Int. 1983;23:647-55.

34. Zatz R, Dunn BR, Meyer TW, Anderson S, Rennke HG, Brenner BM Prevention of diabetic glomerulopathy by pharmacological amelioration of glomerular capillary hypertension. J Clin Invest. 1986;77(6):1925-30.

35. Wanner C, Inzucchi SE, Lachin JM, Fitchett D, von Eynatten M, Mattheus M, Johansen OE, Woerle HJ, Broedl UC, Zinman B, Investigators EMPA-REGOUTCOME. Empagliflozin and progression of kidney disease in type 2 diabetes. N Engl J Med. 2016;375(4):323-34.

Ready to submit your research? Choose BMC and benefit from:

- fast, convenient online submission

- thorough peer review by experienced researchers in your field

- rapid publication on acceptance

- support for research data, including large and complex data types

- gold Open Access which fosters wider collaboration and increased citations

- maximum visibility for your research: over $100 \mathrm{M}$ website views per year

At $\mathrm{BMC}$, research is always in progress.

Learn more biomedcentral.com/submissions 